\title{
Anti-quality effects of insects feeding on rangeland plants: A review
}

\author{
JOHN B. CAMPBELL
}

Author is professor, Department of Entomology, University of Nebraska, West Central Research and Extension Center, Route 4-Box 46A, North Platte, Nebr. 69101-9495.

\begin{abstract}
The anti-quality effects of the major groups of insects that utilize rangeland plants for food is discussed. The biology, ecology, geographical distribution and economic thresholds of grasshoppers, crickets, Western harvester ants, ranch caterpillars, bigeyed or black grass bugs, and white grubs are reviewed. Also discussed are practical pest management strategies if they exist. Most of these rely on the integration of good range management practices and the control strategy.
\end{abstract}

Key Words: Grasshoppers, harvester ants, range caterpillar, big eyed bugs, rangeland insects.

In the United States, over 1,500 species of insects have been noted as being in association with the range ecosystem (Kumer et al. 1976, Thomas and Werner 1981). Fortunately, most of these are not economic in terms of detrimental effects on range plants. The best known damaging species belong to the insect order of Orthoptera-grasshoppers, Hymenoptera-ants and termites, Lepidoptera - caterpillars, Coleoptera-beetles, and Homopteraleafhoppers. Insects are a significant factor in energy flow, nutrient cycling, water utilization and vegetative changes in a range ecosystem.

Many entomology textbooks refer briefly to range insects, but the 2 major publications that deal specifically and exclusively with the subject are Haws et al. (1982) "An Introduction to Rangeland Insects of the Western United States" and Watts et al. (1989) "Rangeland Entomology". This latter publication has been noted as the world's most authoritative treatment on the important role of insects in rangeland ecosystems. Another publication of note is Pfadt (1994) "Field Guide to Common Western Grasshoppers". This publication contains colored plates of adult and nymphs of the major rangeland grasshoppers, and the text details the biology habitat and feeding choices for each species. This publication by itself is a Wyoming Experiment Station Bulletin, but it is included in the USDA-APHIS Technical Bulletin 1809 "Grasshoppers Integrated Pest Management User Handbook". This latter publication contains material by numerous authors on range management considerations to reduce damage from grasshoppers and/or to reduce grasshopper numbers based on range management techniques (Anonymous 1996).

Grasshoppers are the most serious of the insect groups that contribute to the anti-quality of range plants. While there may be 50

\footnotetext{
Manuscript accepted 13 Sept. 00.
}

\section{Resumen}

Se discuten los efectos anti-calidad de los principales grupos de insectos que utilizan las plantas del pastizal como alimento. También se revisó la biología, ecología, distribución geográfica y umbrales económicos de chapulines, grillos, hormigas cosechadoras del oeste, orugas de rancho y pulgas ojonas o chibches negras de zacate y gusanos blancos. También se discuten las estrategias practicas del manejo de plagas, si ellas existen. Muchas de ellas se basan en la integración de buenas practicas de manejo del pastizal y la estrategia de control.

or more species present at a certain type of range, only 8 or 9 species are really causing economic losses. Some species are considered beneficial in that they fed only on plants that are considered detrimental to the range. For example, Hypochlora alba (Dodge) feeds primarily on Louisiana sagewort, Artemsia ludoviciana Nutt., and secondarily on Western ragweed, Ambrosia psilostacka D.C. The genus Hesperottix feeds mainly on Western ragweed and Missouri goldenrod, Solidago missouriensis Nutt., (Campbell et al. 1974).

Grasshoppers are classified as grass feeders, mixed feeders or forb feeders based on the mandibular type. Generally, the outbreak populations belong to the mixed feeder group. Another classification is slant-face, to which most of the grassfeeders belong, and the spur throat to which most of the mixed feeders belong, and band-wings, which are mostly large grasshoppers that may be either mixed or forb feeders.

There are 3 life stages in the grasshopper life cycle-egg, nymph and adult. Eggs are deposited in soil and a frothy, sticky material is secreted with egg deposition which forms an insulated pod composed of soil particles. The number of pods and eggs per pod varies with species. Some species deposit eggs in soil surrounded by roots of grasses; other species select open areas with accumulations of surface debris.

Most grasshopper species overwinter in the egg stage, but a few overwinter as nymphs. Hatching time is influenced by temperature and can be correlated with soil temperature. In the Northern Plains states, cool-season grasses such as needlegrasses (Stipa spp.), wheatgrasses (Agropyron spp.) and bluegrasses (Poa spp.) begin growth before grasshoppers become very active. By the time grasshoppers begin to defoliate plants, these grasses have completed growth and have enough energy reserves needed for spring growth the following year. The warm-season grasses such as the bluestems (Agropogan spp.), grama grasses (Bouteloua spp.) and buffalograss Buchloe doctyloides (Nutt.) Engelm., do not begin growth until May and grow most rapidly when temper- 
atures reach $85-95^{\circ} \mathrm{F}$, which coincides with the greatest grasshopper feeding activity.

Grass responses to defoliation includes stoppage of root growth and nutrient uptake for several days if more than half of the green herbage is removed. "Shutdown" or "slow-down" periods in roots increase as severity and frequency of defoliation increase. Removing more than $65 \%$ of the green herbage one time during the growing season can reduce total root length by $30 \%$ or more. If this occurs over several years, plants become weak and die (Campbell et al. 1998).

Damage caused by grasshoppers is more than actual consumption of forage. They cut stems and blades while eating only part of them. They eat closer to the ground than livestock and may kill growing tips of grasses. They cut off seed stocks, reducing seed production, and soil erosion may result from denudation by heavy populations.

Personnel from the Bureau of Entomology and Plant Quarantine kept seasonal grasshopper density records for western ranges from 1932-1952. They estimated that the average number of 1.2 grasshoppers $/ \mathrm{m}^{2}$ would eat or destroy 14.65 million tons of forage on the 262 million acres of western rangeland. This would have provided feed for another 4.9 million animal units (unpublished data Cowan and Bell 1973).

Crickets are close relatives of grasshoppers and have had sporadic outbreaks for over a century. In outbreak years, they increase in number and form great migratory bands (Watts et al. 1982). During these outbreaks, they may denude the rangeland of practically all plants. They have been reported to feed on 250 species of range plants (Cowan and Shipman 1947). They seem to have a preference for flower and seed parts reducing the reseeding potential of the plants, and if denuding occurs later in the year, the plant wouldn't be able to store nutrients in the roots for overwintering. The Morman cricket has a similar life cycle to grasshoppers except that they are wingless. All crickets in the migratory band move in the same direction, and the movement is about $0.8 \mathrm{~km}$ per day or $40 \mathrm{~km}$ (25 miles) in a season (Ueckert 1970).

\section{Western Harvester Ants}

The genus Pogonomyrinex is the primary group of harvester ants in North America. Cole (1968) has described 22 species. This group ranks next to grasshoppers in terms of rangeland damage. Lavigne and Fisser (1966) indicate the mounds created by the ants may be a foot high and 30 feet in diameter. The area around the mound is denuded of all vegetation. Not only is the vegetation destroyed, but wind erosion increases in the denuded areas. The ants also collect seeds that may affect plant production, particularly with annual plants. Colonies survive for 15-20 years, and one mound may consist of as many as 60 chambers. Winged reproductive ants may appear in May after a rain, but some also appear in the summer and fall. New colonies are formed by mated queens usually in later summer. After mating, the queen sheds her wings and digs a burrow several inches deep in the soil. The first brood is composed mostly of female workers. This brood forages, enlarges the colony, cares for the young and protects the mound. The workers move the eggs of the second brood to newly-constructed chambers which have been stocked with seeds and insect parts as a food source.

Most of the mound expansion is in the spring, but there is no regrowth in the denuded area later in the season. Lavigne and Fisser (1966) estimated that a single acre of rangeland supported as many as 15 colonies. Worker ants from this number of colonies stripped vegetation from as much as one-seventh of an acre. As is true for grasshoppers, overgrazed range suffers the most damage from the red harvester ant. Grazing management will serve to slow the increase of new mounds. Insecticides can be used to treat the mounds, but this is labor intensive and should be approached from an area-wide control effort to be successful.

\section{Rangeland Caterpillar-Hemilenca oliviae Cockerill}

The range caterpillar has 3 discontinuous populations, one in Mexico, one in southcentral New Mexico and the third in northeastern New Mexico, Colorado, Oklahoma and Texas. Dubach et al. (1988) and Shaw et al. (1987) believe these were once a continuous population. Currently the distribution of the 3 populations are separated by brush-infested areas which may have been devoid of brush in earlier times. The caterpillar distribution is generally in blue grama-dominated rangeland at elevations between 1,350 and 2,400 meters. The northern distribution into Colorado is probably limited by decreasing late summer precipitation.

Caterpillars consume grass, often down to the crown, waste unconsumed portions of leaves as do grasshoppers, and in addition, discourage grazing because of urtrication spines from both the larvae and their shed skins. These spines cause irrita- tion around the mouth and nose of livestock. The larvae may tie several grass stems together with the cast skin. Livestock tend to avoid grazing in these areas because of the spines.

As the populations become larger, food consumption is heavy. They may destroy all of the green grass down to and including some of the crown. If drought conditions exist, there is little regrowth, and the roots are unable to store nutrients for the winter, and there is no reseeding of annual plants.

As they search for food, caterpillars gather in bands a meter or more wide and several kilometers in length. Ranchers refer to the feeding of these bands as "windrowing". The range caterpillar feeds on 40 or more species of grass (Wildermuth and Caffrey 1916, Capinera 1978). Huddleston et al. (1976) established the economic threshold as 2 large larvae $/ \mathrm{m}^{2}$. Similar values were derived by laboratory and model studies (Bellows et al. 1983, Capinera et al. 1983, Riley et al. 1984).

The adult range caterpillar is a buff to brown moth with a wing span of 50-70 $\mathrm{mm}$. The female mates and deposits eggs and dies within about 3 days. Eggs are deposited in cylinder-shaped clusters on plants. Larvae undergo six molts before pupating. This takes $12-14$ weeks if hatch occurs in the spring but only 7 or 8 if the hatch occurs in the summer.

The range caterpillar has in the past been considered cyclic which is probably true in the sense of large populations in extensive areas. In recent years, some extensive damage has occurred in localized areas virtually every year.

Control has changed from massive aerial spray programs over large areas to smaller mist applications of pyrethroids to localized areas. If the infestation is early and appropriate timing of insecticide applications occurs in a year with at least some moisture, grassy vegetation may recover.

\section{White Grubs}

Beetles from the family Scarabaeidae are among the most numerous on range. Those beetles that have grubs as the immature stage are the most damaging. In most species, plant damage occurs from the grubs feeding on roots which kills the grass; however, adults of a few species also cause plant damage. Kumer et al. (1976) collected 37 species from shortgrass prairie in northeastern Colorado. Only 9 species of the group were associated with root feeding, most of the rest were dung beetles. The Phyllophaga spp. complex are the best known plant damaging group (Anonymous 1971a, 1971b). 
The white grubs (May-June beetles) are creamy white with a shiny brown head, have 6 prominent legs and are generally shaped like a "C". Much of the damage on rangeland probably goes unnoticed if it is of moderate intensity. It is generally diagnosed as plant stress as a result of drought.

Heavy damage may occur only in spots ranging from $10-100$ meters in diameter. In some areas such as the Nebraska Sandhills, damage may occur only in wet meadows that are a valuable hay or grazing source. In addition to destruction of the grass, other problems may occur. Annual weeds often invade and dominate the area for a number of years (Randolph and Garner 1961). Drake (1964) suggests that feeding by white grubs creates a mode of entry for bacterial and fungal diseases that kill the weakened plant.

Skunks and other rodents may cause further damage to plants by digging up grubs as a food source. This occurs in Nebraska in the wet meadow areas. Although there are certain cultural or chemical control measures that reduce grub numbers, they would only be economical to employ where a crop such as wheat is concerned. There is no practical economic method for control of white grubs on rangeland.

The life cycle of the white grub may take 3-4 years dependent on the species and climate. Most of the damage is done in the second year. The beetles deposit eggs in late spring or early summer. Some feeding occurs the first season. Grubs move below the frost line until spring, then move close to the surface to feed on roots. The same procedure occurs each year in the cycle. When the larval cycle has been completed, an earthen cell is prepared and pupation occurs within the cell. The adults remain in the cell until spring when they emerge and start another generation.

\section{Miridae (Plant bugs)}

Many species of this family are associated with range plants. They have piercing sucking mouth parts with which they suck juices from plants.

The black grass bugs are the best known of this group of insects. They are also called big-eye bugs because their eyes appear to be bulging from the side of their heads. There are 34 species from 2 genera; Labops and Irbisia in this group (Kelton 1980).

Insects such as black grass bugs that feed by sucking fluids from the cell have considerable impact on range plant quality, quantity and plant survival (Haws et al. 1982). The adults of this group are about 6 $\mathrm{mm}$ long and are blackish grey, with buff margins around the edges of the wing.
Labops have vestigial hind wings, but Irbisia have well-developed wings.

Adult females of the big-eyed bugs deposit eggs into grass stems in the fall. The nymphs hatch in the spring in the warmer lower areas and later in the cooler upland areas.

The black grass bugs were first noted as pests around 1950 when range improvement programs were replacing native grasses with introduced grasses especially wheatgrasses. The large areas of a single species of grass provided an excellent niche for the black grass bugs (Higgins et al. 1977). A density of $156 / \mathrm{m}^{2}$ reduced seed head production in intermediate wheatgrass by 56\% (Malechek et al. 1977). Ansley and McKell (1982) showed the black grass bug feeding reduced leaf length, seedhead height and carbohydrate reserves in root crowns in crested wheatgrass.

Control strategies include application of insecticides, (Hagen 1975, Dickerson 1978) or heavy grazing in the spring, (Kamm and Fuxa 1977, Hagen 1975). Insect resistant varieties have also been evaluated. Hewitt (1980) reported that tall, slender, intermediate and pubescent wheatgrasses were somewhat tolerant to feeding by the black grass bugs.

There are many other insect species that may sporadically cause severe damage to rangeland in some limited areas. Termites, armyworms, army/cutworms, leafhoppers, plant hoppers, spittle bugs, wireworms, billbugs and numerous others feed on range plants, but generally are not numerous enough to warrant expensive control techniques.

One other group of insects I was requested to mention are blister beetles. Blister beetles are generally considered beneficial in that the larvae of several species are predacious on grasshopper eggs. Others are predaceous in the cells of ground-dwelling species of bees.

Adult blister beetles tend to be gregarious, and several may be noted feeding on the same flowering alfalfa plant. They also feed on soybeans and blooming goldenrod and probably other plant species found in a range plant complex.

Adult blister beetles vary in size and color, but are easily recognized by the elongated, narrow, cylindrical and soft bodies. When viewed from above, they have a constriction at the back of the head where it attaches to the narrowed anterior end of the thorax (Bauernfeind and Breeden 1984). The life cycle of blister beetles is complex with several different immature forms. Clusters of eggs are deposited in the ground. Newly-hatched larvae move through the soil feeding on grasshopper egg pods. This larval stage is termed triungulin. Within a month, the larvae pass through three more stages with each becoming more sedentary. Finally, they change to the pseudopupae which is the overwintering stage. As temperature and moisture increase in the spring, they enter the final immature pupal stage from which adults emerge. There is 1 generation per year.

The interest in the blister beetles is not from the standpoint of damage to range plants but because of the injury to horses or other livestock. They may actually ingest a blister beetle. The bodies of the blister beetles contain a vesicant substance called cantharidan. This substance causes blisters on skin tissue upon contact. It is usually ingested with the consumption of alfalfa hay. Horses are very susceptible to blister beetle poisoning. Portions or all of the horse digestive tract can be severely irritated bringing about secondary infections and bleeding (Bauernfeind and Breeden 1984). Cantharadin is absorbed and excreted through the kidneys, thus irritation of the kidney, ureter, urinary bladder and urethra could be followed by secondary infections and bleeding. The substance also lowers calcium levels and causes damage to heart muscle tissue.

Capinera et al. (1985) conducted cantharadin analysis on several species of blister beetles commonly found in Colorado. There were differences in amounts found between species and sexes. Males apparently produce cantharadin and pass it to females at mating. The minimum lethal dose of catharadin is about 1 $\mathrm{mg} / \mathrm{Kg}$. Thus a few beetles with a high catharadin level would kill a small horse, but quite a few with a low level would be required to kill a large horse.

Extension entomologists field quite a few questions yearly from either horse owners or alfalfa producers on how to avoid buying or selling alfalfa hay that contains blister beetles. Generally, blister beetles are present at the second and third cuttings, but probably will not be in the first or fourth cuttings; however, in 1998 in Nebraska, blister beetles were still present at the time of the fourth cutting. Inspection of bales is not practical because the gregarious behavior of the beetles might cause one bale to have a large number of beetles, and the next bale might not have any. For the same reason, chemical control is probably not practical either unless hay for horses was bringing a premium price. Dead beetles are still toxic. Killing the beetles doesn't reduce the toxicity. 


\section{Literature Cited}

Anonymous. 1971a. White grubs - Nebraska. USDA Coop. Econ. Insect Rept. 21:373

Anonymous. 1971b. White grubs-Colorado. USDA Coop. Econ. Insect Rept. 21:488.

Anonymous. 1996. Grasshopper IPM User Handbook. Tech. Bull. No. 1809. USDA-APHIS.

Ansley, R.J. and C.M. McKell. 1982. Crested wheatgrass vigor as affected by black grass bug and cattle grazing. J. Range Manage. 35:586-590.

Bauernfeind, R.J. and L.D. Breeden. 1994. Blister beetles. Kans. St. Univ. Ext. Ser. Ag Facts Entomol. 111. 4 pp.

Bellows, T.S., J.C. Owens, and E.W. Huddleston. 1983. Model for simulating consumption and economic injury level for the range caterpillar. (Lepidoptera: Saturniidae). J. Econ. Entomol. 76:1231-38.

Campbell, J.B., P.E. Reece, and G.L. Hein. 1998. Range and pasture insects. Chap. 19. High Plains integrated pest management guide-Colorado, western Nebraska and Wyoming. Bull. 564A. pp. 1-6.

Campbell, J.B., W. Harold Arnett, J.D. Lambley, O.K. Jantz, and H. Knutson. 1974. Grasshoppers (Acrididae) of the Flint Hills native prairie in Kansas. Kans. St. Univ. Agr. Exp. Sta. Res. Paper No. 19. 147 pp.

Capinera, J.L. 1978. Studies of host plant preference and suitability exhibited by early instar range caterpillar larvae. Environ. Entomol. 7:738-40

Capinera, J.L., J.K. Detling, and W.J. Parton. 1983. Assessment of range caterpillar (Lepidoptera:Saturniidae) effects with a grassland simulation model. J. Econ Entomol. 76:1088-1094.

Capinera, J.L., D.R. Gardner, and F.R. Stermitz. 1985. Cantharidin levels in blister beetles (Coleoptera:Meloidae) associated with alfalfa in Colorado. J. Econ. Entomol. 78:1052-55.

Cole, C., Jr. 1968. Pogonomyrmex Harvester Ants: A study of the genus in North America. Tenn. Press; Knoxville, Tenn. 222 pp.

Cowan, F.T. and H. Shipman. 1947. Quantity of food consumed by Morman crickets. J. Econ. Entomol. 40:825-828.

Dickerson, G.W. 1978. Control of black grass bugs (Labops hesperins Uhler) in northern New Mexico. J. Range Man. 3:398-99.

Drake, C. 1964. The relationship of white grubs, facultative fungi and bacteria on the decline of birdsfoot trefoil. Plant Dis. Rept. 48:406-8.

Dubach, J.M., D.B. Richman, and R.B. Turner. 1988. Genetic and morphological variation among geographical populations of the range caterpillar Hemilenca oliviae (Lepidoptera:Saturniidae) Ann. Entomol. Soc. Amer. 81:132-7.

Hagen, A.F. 1975. Crested wheatgrass. L. hesperins control. Insect and Acar. Tests. 1:102.
Haws, B.A., J.F. Werner, D.B. Thomas, J.L. Capinera, R.W. Lauderdale, J.B. Knight, E.W. Huddleston, W. Smith, W.C. Campbell, J.D. Evans, A.F. Glover, B.E. Norton, and E. Arlo Richardson. 1982. Rangeland Insects of the Western United States. Utah Agr. Exp. Sta. Spec. Rept. 23. $64 \mathrm{pp}$.

Hewitt, G.B. 1980. Tolerance of ten species of Agropyron to feeding by Labops hesperins. J. Econ. Entomol. 73:779-782.

Higgins, K.M., J.E. Browns and B.A. Haws. 1977. The black grass bug, Labops hesperins Uhler; its effect on several native and introduced grasses. J. Range Manage. 30:380-84.

Huddleston, E.W., E.M. Dressel, and J.G. Watts. 1976. Economic thresholds for range caterpillar larvae on bluegramma pasture in northeastern Lincoln County, New Mexico in 1975. N. Mex. Agr. Exp. Sta. Res. Rept. 314. $4 \mathrm{pp}$.

Kamm, J.A. and J.R. Fuxa. 1977. Management practices to manipulate populations of the plant bug Labops hesperins Uhler. J. Range Manage. 30:385-87.

Kelton, L.A. 1980. The insects and arachnids of Canada, Part 8. The plant bugs of the Prairie Provinces of Can. Res. Brit. Agr. Can. Pub. 1703. 401 pp.

Kumer, R., R.J. Lavigne, J.E. Lloyd, and R.E. Pfadt. 1976. Insects of the Central Plains experimental range, Pawnee National Grassland. Wyo. Agr. Exp. Sta. Div. Monogr. $32.74 \mathrm{pp}$

Lavigne, R.J. and H.G. Fisser. 1966. Controlling western harvester ants. Mtn. Sta. Reg. Publ. No. 3. 4 pp.

Malechek, J.C., A.M. Gray, and B.A. Haws. 1977. Yield and nutritional quality of intermediate wheatgrass infested with black grass bugs at low population densities. J. Range. Manage. 30:128-131.

Pfadt, R.E. 1994. Field guide to common western grasshoppers. Wyo. Agr. Exp. Sta. Bull. 912. $40 \mathrm{pp}$.

Randolph, N.M. and C.F. Garner. 1961. Insects attacking forage crops. Tex. Agr. Ext. Ser. Bull. B-975. 2 pp.

Riley, S.L., T.S. Bellows, Jr., J.C. Owens, and E.W. Huddleston. 1984. Consumption and utilization of bluegramma grass Bontelona gracilis by range caterpillar larvae. Hemilenca oliviae (Lepidoptera:Saturniidae). Environ. Entomol. 13:29-35.

Shaw, P.B., D.B. Richman, J.C. Owens and E.W. Huddleston. 1987. Ecology of the range caterpillar, Hemilenca oliviae Cockrell. In: Capinera, J.L. Ed. Integrated pest management on rangeland. A shortgrass prospective. Westview Press, Boulder Colo. pp. 234-247.

Thomas, D.B. and F.G. Werner. 1981. Grass feeding insects of the Western ranges: an annotated checklist. Univ. of Ariz. Agr. Exp. Stat. Tech. Bull. No. 243. 50 pp.

Ueckert, D.N. 1970. Seasonal dry-weight composition in diets of Morman crickets. J. Econ. Entomol. 63:96-98.
Watts, J.G., E.W. Huddleston, and J.C. Owens. 1982. Rangeland entomology. Ann. Rev. Entomol. 27:283-311.

Watts, J. Gordon, G.B. Hewitt, E.W. Huddleston, H. Grant Kinzer, R.J. Lavigne and D.N. Ueckert. 1989. Rangeland Entomology. Range Sci. Series No. 2. $2^{\text {nd }}$ ed. 388 pp.

Wildermuth, V.L. and D.T. Caffrey. 1916. The New Mexico range caterpillar and its control. USDA Bull. 443. 12 pp. 